\title{
The clinical impact of hepatitis $C$ virus infection in Egyptian multiple myeloma patients
}

\author{
Neemat M. Kassem ${ }^{1}$, Hebatallah A. Kassem ${ }^{1 *}$ (D) Magdy Ibrahim², Hussam Zawam³ and Emad Hamada ${ }^{3}$
}

\begin{abstract}
Background: Multiple myeloma (MM) is a human B cell neoplasia characterized by the clonal proliferation of malignant plasma cells in the bone marrow. Worldwide, hepatitis $\mathrm{C}$ virus $(\mathrm{HCV})$ infection is a public health problem. For MM patients, the clinical impact of preexisting HCV infection is still unclear. We aim to assess the clinical characteristics and the prevalence of the HCV infection in Egyptian MM patients. This observational study included $81 \mathrm{MM}$ patients. HCV antibody assay was performed, and positive cases were confirmed using a reverse transcription-quantitative PCR (RT-PCR) method.

Results: Fifteen (18.5\%) patients were anti-HCV antibody positive. Only 6/15 (7.4\%) patients were HCV RNA positive by RT-PCR. Liver affection in the form of hyperbilirubinemia with grade 4 adverse events was significantly higher in the anti-HCV positive/HCV RNA positive group versus anti HCV negative group (16.7\% vs. $1.5 \%, p$ value $=0.005)$. The median HCV-RNA before the initiation of chemotherapy was $2.5 \mathrm{log} \mathrm{IU} / \mathrm{ml}$ with mean $\pm \mathrm{SD}=4.25 \pm 1.6$ with no HCV reactivation. In the univariate and multivariate analysis, HCV infection was not an independent factor related to DFS. Low hemoglobin level $<10 \mathrm{~g} / \mathrm{dL}(\mathrm{HR} \mathrm{0.59,95 \%} \mathrm{Cl,} \mathrm{0.36-0.97,} p$ value $=0.037)$ and abnormal serum total bilirubin level (HR 1.9, 95\% Cl 1.03-3.5, $p$ value $=0.039)$ influenced DFS in the univariate analysis. However, in the multivariate analysis, serum calcium level greater than $12 \mathrm{mg} / \mathrm{dL}$ (HR 7.04, 95\% Cl 1.12-44.45, $p$ value $=0.038$ ) and abnormal serum total bilirubin level $(\mathrm{HR} 10.9,95 \% \mathrm{Cl} 2.92-41.02, p$ value $=<0.001)$ remained statistically significant worse prognostic factors.
\end{abstract}

Conclusion: In conclusion, our study revealed the prevalence of HCV infection in Egyptian MM patients. Serologic tests at diagnosis are necessary to identify these patients, and confirmation of positive cases by molecular techniques should be mandatory, with regular follow-up for liver dysfunction. Finally, further larger studies explaining the molecular mechanisms linking HCV and the MM pathogenesis are warranted.

Keywords: Hepatitis C virus, Multiple myeloma, Prevalence, Hepatic adverse events

\footnotetext{
* Correspondence: Heba.kasem@hotmail.com

${ }^{1}$ Clinical and Chemical Pathology Department, Kasr Al Ainy Centre of Clinical Oncology \& Nuclear Medicine, School of Medicine, Cairo University, Cairo,

Egypt

Full list of author information is available at the end of the article
}

(c) The Author(s). 2020 Open Access This article is licensed under a Creative Commons Attribution 4.0 International License, which permits use, sharing, adaptation, distribution and reproduction in any medium or format, as long as you give appropriate credit to the original author(s) and the source, provide a link to the Creative Commons licence, and indicate if changes were made. The images or other third party material in this article are included in the article's Creative Commons licence, unless indicated otherwise in a credit line to the material. If material is not included in the article's Creative Commons licence and your intended use is not permitted by statutory regulation or exceeds the permitted use, you will need to obtain permission directly from the copyright holder. To view a copy of this licence, visit http://creativecommons.org/licenses/by/4.0/. 


\section{Background}

Multiple myeloma (MM) is a human B cell neoplasia characterized by the clonal proliferation of malignant plasma cells (PCs) in the bone marrow (BM) [1]. MM has been raised from an asymptomatic premalignant proliferation of monoclonal plasma cells that are derived from post-germinal-center B cells. The etiology of MM is poorly understood. Genetic and micro-environmental changes induce transformation of these premalignant cells into the malignant stage. Genomic studies suggest that a dominant mutation cluster has been identified in $R A S / R A F$ genes, emphasizing the potential significance of RAS/RAF/MEK/ERK signaling as a therapeutic target [2]. Mutation of genes such as iKRAS, NRAS, TP53, $F A M 46 C, D I S 3$, and $B R A F$ has a high recurrence rate and may play important roles in the pathogenesis, progression, and prognosis of MM [3]. Polymerase chain reactions (PCR), stripassay, and sequencing studies have been used to determine such genetic mutations in cancer patients [4]. Also, interactions between myeloma cells and BM stromal cells or extracellular matrix proteins that are mediated through cell-surface receptors (e.g., integrins, cadherins, selectins, and cell-adhesion molecules) increase tumor growth, survival, migration, and also drug resistance [5]. Despite the recent therapeutic options to treat $\mathrm{MM}$, it remains an incurable condition for the majority of patients, with a median survival of 3-5 years [6]. In Egypt, an estimated 871 new MM cases in 2018 were found, representing $0.68 \%$ of all new cancer cases. The number of MM-related deaths accounts for nearly 783 deaths (0.92\% of all deaths) [7]. Worldwide, hepatitis $\mathrm{C}$ virus ( $\mathrm{HCV}$ ) infection is a public health problem where its seroprevalence had an estimated $2.8 \%$ elevation in the last decade, equal to more than 185 million infections (3\% of the world's population) [8]. Recent assessment revealed that 119 million global adult inhabitants have chronic HCV infection, with 3-4 million new infections and 350,000 to 500,000 deaths occurring each year as a result of HCV-related complications. $\mathrm{HCV}$ is the main source of chronic hepatitis, liver cirrhosis, and hepatocellular carcinoma (HCC). About 55-85\% of HCV-infected patients become chronic active cases passing to fibrosis, cirrhosis, and may progress till decompensated cirrhosis and HCC [9]. In Egypt, $\mathrm{HCV}$ infection has been a public health problem. The predominance of $\mathrm{HCV}$ infection is highest in Egypt ranging from 6 to 40\% with an average of 14\%. Approximately, $75 \%$ of the individuals are constantly asymptomatic and remain undiagnosed [10]. The association between chronic HCV infection and lymphoproliferative diseases such as non-Hodgkin's lymphoma, Hodgkin's lymphoma, and MM has been discussed for a long time $[11,12]$. Patients with viral hepatitis infections have been suggested to have a higher risk of MM.
However, the association between $\mathrm{HCV}$ infection and MM remains controversial [11]. Other various studies revealed a higher incidence of $\mathrm{HCV}$ infection in $\mathrm{MM}$ patients than healthy control populations [13]. The aim of the current study is to assess the clinical characteristics and the prevalence of the hepatitis $C$ virus infections in Egyptian multiple myeloma patients.

\section{Methods \\ Study population}

This observational study included $81 \mathrm{MM}$ patients who were diagnosed as myeloma based on the criteria proposed by the International Myeloma Working Group [6], and all patients were staged at diagnosis according to the International Staging System (ISS). Patients were recruited from our clinical oncology department and were scheduled to receive standard MM treatment throughout the last 2 years. Patients diagnosed with monoclonal gammopathy of undetermined significance (MGUS), POEMS (polyneuropathy, organomegaly, endocrinopathy, monoclonal gammopathy, and skin changes) syndrome, smoldering MM, and solitary plasmacytoma were excluded from this study. Also, cases without HCV serologic test results were excluded. Baseline patient and tumor characteristics, in addition to treatment received were recorded. The study was approved by the Research Ethical Committee of Clinical Oncology department, and informed consents were obtained from all participants prior to enrollment in the study.

\section{Assessment of HCV infection status}

\section{Qualitative assessment of hepatitis $C$ virus antibodies}

Hepatitis $\mathrm{C}$ virus antibody ( $\mathrm{HCV} \mathrm{Ab)} \mathrm{assay} \mathrm{was} \mathrm{performed}$ using the automated ABBOTT Architect i1000 SR system (Singapore, USA). The Architect HCV Ab assay uses chemiluminescent microparticle immunoassay (CMIA) technology for detection of HCV Ab in human serum or plasma blood samples. Negative samples which did not react were considered as non-reactive for HCV antibodies, while reactive samples were considered as positive for $\mathrm{HCV}$ antibodies. Reactive samples will be confirmed using a reverse transcription-PCR (RT-PCR) method.

\section{Quantitative assessment of hepatitis C virus by RT-PCR}

The molecular HCV RNA assay is a confirmatory test with a lower limit of sensitivity of $20 \mathrm{IU} / \mathrm{mL}$ which uses RT-PCR technology using StepOne Real-Time PCR machine (Applied Bio-systems, USA). Plasma was isolated from EDTA peripheral blood samples through centrifugation at $800-1600 \times g$ for $20 \mathrm{~min}$. RNA was extracted from $140 \mu \mathrm{L}$ of plasma using QIAamp Viral RNA miniKit (Qiagen, Germany) according to the manufacturer's protocol. The extracted RNA was eluted in elution buffer and used for the quantitative RNA PCR. Quantitative 
RT-PCR was done according to the manufacturer's protocol using a commercial HCV kit (Artus HCV RTPCR CE Kit, Qiagen, Germany). For determination of the viral load, the threshold cycle $(\mathrm{Ct})$ value was used against standard curve to determine the viral load.

\section{Hepatitis $C$ virus reactivation}

$\mathrm{HCV}$ reactivation was defined as tenfold or more increase in the HCV RNA level following chemotherapy compared with the baseline level [14]. Our study compared changes in HCV viral load prior to and after chemotherapy. Acute exacerbation of chronic HCV infection was defined as a threefold or greater elevation in serum ALT level in the absence of (1) infiltration of the liver by tumor, (2) use of hepatotoxic drugs (other than chemotherapeutics), (3) recent blood transfusion (within 1 month of ALT level elevation), or (4) other systemic infections (including hepatitis A, HBV, cytomegalovirus, adenovirus, herpes simplex virus, varicella zoster virus, and human immunodeficiency virus infections) [10].

\section{Treatment regimen and response to therapy}

All MM patients received bortezomib-based therapy that included bortezomib/cyclophosphamide/dexamethasone or bortezomib/thalidomide/dexamethasone for at least 3-4 months in our clinical oncology department. Patients with younger ages $(<60$ years old $)$ and high disease burden received induction therapy by VRD (velcade-lenalidomidedexamethasone). In our study, patients with age $>70$ years old to whom the ministry of health does not approve bortezomib therapy, received endoxan-dexamethasone and then maintained by lenalidomide-dexamethasone. Patients with younger age $(<60$ years) and no comorbidities who attain complete remission $(\mathrm{CR})$, very good partial response

Table 1 Characteristics of $81 \mathrm{MM}$ patients according to their HCV status

\begin{tabular}{|c|c|c|c|c|c|}
\hline \multirow[t]{2}{*}{ Items } & & \multicolumn{3}{|l|}{ No. of patients (\%) } & \multirow[t]{2}{*}{$P$ value } \\
\hline & & $\begin{array}{l}\text { Ab (-)ve } \\
\text { No. = } 66(81.5 \%)\end{array}$ & $\begin{array}{l}\text { Ab (+)ve/PCR (-)ve } \\
\text { No. }=9(11.1 \%)\end{array}$ & $\begin{array}{l}\text { Ab (+)ve/PCR (+)ve } \\
\text { No. }=6(7.4 \%)\end{array}$ & \\
\hline \multicolumn{2}{|c|}{ Age $>65$ years } & $3(4.5 \%)$ & $2(22.2 \%)$ & $0(0.0 \%)$ & 0.095 \\
\hline \multirow[t]{2}{*}{ Gender } & Male & $30(45.5 \%)$ & $5(55.6 \%)$ & $4(66.7 \%)$ & 0.545 \\
\hline & Female & $36(54.5 \%)$ & $4(44.4 \%)$ & $2(33.3 \%)$ & \\
\hline \multicolumn{6}{|c|}{ Serum M-protein: } \\
\hline \multicolumn{2}{|l|}{ FLC } & $2(3.0 \%)$ & $0(0.0 \%)$ & $0(0.0 \%)$ & 0.806 \\
\hline \multicolumn{2}{|l|}{ IgAK } & $3(4.5 \%)$ & $0(0.0 \%)$ & $0(0.0 \%)$ & \\
\hline \multicolumn{2}{|l|}{$\lg A L$} & $1(1.5 \%)$ & $0(0.0 \%)$ & $0(0.0 \%)$ & \\
\hline \multicolumn{2}{|l|}{ IgGK } & $50(75.8 \%)$ & $9(100.0 \%)$ & $6(100.0 \%)$ & \\
\hline \multicolumn{2}{|l|}{$\operatorname{lgGL}$} & $10(15.2 \%)$ & $0(0.0 \%)$ & $0(0.0 \%)$ & \\
\hline \multicolumn{6}{|c|}{ ISS stage: } \\
\hline \multicolumn{2}{|l|}{ । } & $14(21.2 \%)$ & $0(0.0 \%)$ & $0(0.0 \%)$ & 0.114 \\
\hline \multicolumn{2}{|l|}{$\|$} & $24(36.4 \%)$ & 7 (77.8\%) & $3(50.0 \%)$ & \\
\hline \multicolumn{2}{|l|}{ III } & $28(42.4 \%)$ & $2(22.2 \%)$ & $3(50.0 \%)$ & \\
\hline \multicolumn{2}{|c|}{$\beta 2 \mathrm{~m} \geq 3.5 \mathrm{mg} / \mathrm{L}$} & $12(25.5 \%)$ & $3(37.5 \%)$ & $0(0.0 \%)$ & 0.310 \\
\hline \multicolumn{2}{|c|}{ Albumin $<3.5 \mathrm{~g} / \mathrm{L}$} & $38(58.5 \%)$ & $8(88.9 \%)$ & $4(66.7 \%)$ & 0.205 \\
\hline \multicolumn{2}{|c|}{ Hemoglobin $<10 \mathrm{~g} / \mathrm{dL}$} & $31(47.0 \%)$ & $6(66.7 \%)$ & $1(16.7 \%)$ & 0.164 \\
\hline \multicolumn{2}{|c|}{ Platelets $<100 \times 10^{9} / \mathrm{L}$} & $7(10.6 \%)$ & $3(33.3 \%)$ & $0(0.0 \%)$ & 0.096 \\
\hline \multicolumn{2}{|c|}{ Serum calcium $\geq 12.0 \mathrm{mg} / \mathrm{dL}$} & $51(96.2 \%)$ & $9(100.0 \%)$ & $5(83.3 \%)$ & 0.762 \\
\hline \multicolumn{2}{|c|}{ Serum creatinine $\geq 2.0 \mathrm{mg} / \mathrm{dL}$} & $58(89.2 \%)$ & $6(66.7 \%)$ & $6(100.0 \%)$ & 0.100 \\
\hline \multicolumn{6}{|c|}{ Response to MM treatment: } \\
\hline \multicolumn{2}{|l|}{$C R$} & $10(15.2 \%)$ & $0(0.0 \%)$ & $3(50.0 \%)$ & 0.100 \\
\hline \multicolumn{2}{|l|}{ VGPR } & $10(15.2 \%)$ & $0(0.0 \%)$ & $0(0.0 \%)$ & \\
\hline \multicolumn{2}{|l|}{ PR } & $23(34.8 \%)$ & $7(77.8 \%)$ & $2(33.3 \%)$ & \\
\hline \multicolumn{2}{|l|}{ PD } & $13(19.7 \%)$ & $1(11.1 \%)$ & $0(0.0 \%)$ & \\
\hline \multicolumn{2}{|l|}{ ST } & $10(15.2 \%)$ & $1(11.1 \%)$ & $1(16.7 \%)$ & \\
\hline
\end{tabular}

$H C V$ hepatitis $C$ virus, FLC free light chain, $\beta 2 m$ beta-2-microglobulin, ISS International Staging System, ALT alanine transaminase, $A S T$ aspartate aminotransferase, T.bil total bilirubin, $C R$ complete remission, VGPR very good partial response, $P R$ partial response, $P D$ progressive disease, $S T$ stationary disease 
(VGPR), or partial response (PR) were considered for autologous stem cell transplantation (ASCT) then maintenance by lenalidomide-dexamethasone, while those with older age and/or comorbidities were considered for maintenance by lenalidomide-dexamethasone.

\section{Data analysis}

Data were statistically described in terms of mean \pm standard deviation $( \pm \mathrm{SD})$, median and range, or frequencies (number of cases) and percentages when appropriate. Numerical data were tested for the normal assumption using Shapiro-Wilk test. Comparison between HCV status groups was done using Chi-square $\left(\chi^{2}\right)$ test. Exact test was used instead when the expected frequency is less than 5 . Survival analysis was done for disease-free survival (DFS) using Kaplan-Meier statistics calculating the mean and median survival time for each group with their 95\% confidence interval (CI) and the corresponding survival graphs. Comparison was done between the different factors by Log rank method using Cox-Mantel equation. Univariate and multivariate Cox regression analysis was used to determine the preferential predictors of DFS. Two-sided $p$ values less than 0.05 were considered statistically significant. All statistical calculations were done using computer program IBM SPSS (Statistical Package for the Social
Science; IBM Corp, Armonk, NY, USA) release 22 for Microsoft Windows.

\section{Results}

Our 81 MM patients were 39 males and 42 females with a male to female ratio 0.93 . Their ages ranged between 32 and 75 years with a mean value of $52.2 \pm 9.7$ years and median of 53 years. According to $\mathrm{HCV}$ status, 66/81 (81.5\%) patients are anti-HCV negative and 15/81 (18.5\%) patients are anti-HCV positive. Out of 15 anti-HCV positive patients, 9 (11.1\%) patients are HCV RNA negative by RT-PCR, while the remaining patients $(6 / 15 ; 7.4 \%)$ are HCV RNA positive by RT-PCR. Patients' baseline clinical and laboratory features are shown in Table 1. To investigate the incidence of hepatic adverse events in multiple myeloma patients, alterations in the ALT, AST, and total bilirubin levels were recorded throughout the treatment course. The incidence of hepatic adverse events during the entire treatment course is shown in Table 2. Regarding ALT and AST elevation, there is no significant difference between anti-HCV negative group and anti-HCV positive group whether HCV RNA by RT-PCR was negative or positive ( $p$ value $=0.88$ and 0.22 ), respectively. Hyperbilirubinemia with grade 4 adverse events was significantly higher in the anti-HCV positive/HCV RNA positive group

Table 2 Hepatic adverse effects among 81MM patients

\begin{tabular}{|c|c|c|c|c|}
\hline \multirow[t]{2}{*}{ Items } & \multicolumn{3}{|l|}{ No. of patients (\%) } & \multirow[t]{2}{*}{$P$ value } \\
\hline & Ab (-)ve $n=66(81.5 \%)$ & Ab (+)ve/PCR (-)ve $n=9(11.1 \%)$ & Ab (+)ve/PCR (+)ve $n=6(7.4 \%)$ & \\
\hline \multicolumn{5}{|c|}{ Child-Pugh score (patients) } \\
\hline$A$ & 47 (71.2\%) & $4(44.4 \%)$ & $5(83.3 \%)$ & \multirow[t]{2}{*}{0.195} \\
\hline$B$ & 19 (18.8\%) & $5(55.6 \%)$ & $1(16.7 \%)$ & \\
\hline \multicolumn{5}{|c|}{ ALT increase } \\
\hline Grade 0 & 65 (98.4\%) & 9 (100.0\%) & $6(100.0 \%)$ & \multirow[t]{4}{*}{0.885} \\
\hline Grade 1 & $0(0.0 \%)$ & $0(0.0 \%)$ & $0(0.0 \%)$ & \\
\hline Grade 2 & $0(0.0 \%)$ & $0(0.0 \%)$ & $0(0.0 \%)$ & \\
\hline Grade 3 & $1(1.6 \%)$ & $0(0.0 \%)$ & $0(0.0 \%)$ & \\
\hline \multicolumn{5}{|c|}{ AST increase } \\
\hline Grade 0 & 57 (86.4\%) & $6(66.7 \%)$ & $3(50.0 \%)$ & \multirow[t]{4}{*}{0.222} \\
\hline Grade 1 & $7(10.6 \%)$ & $3(33.3 \%)$ & $2(33.3 \%)$ & \\
\hline Grade 2 & $1(1.5 \%)$ & $0(0.0 \%)$ & $1(16.7 \%)$ & \\
\hline Grade 3 & $1(1.5 \%)$ & $0(0.0 \%)$ & $0(0.0 \%)$ & \\
\hline \multicolumn{5}{|c|}{ Total bil. increase } \\
\hline Grade 0 & $56(85 \%)$ & $5(55.6 \%)$ & $4(66.7 \%)$ & \multirow[t]{5}{*}{$0.005^{*}$} \\
\hline Grade 1 & $3(4.5 \%)$ & $4(44.4 \%)$ & $1(16.7 \%)$ & \\
\hline Grade 2 & $3(4.5 \%)$ & $0(0.0 \%)$ & $0(0.0 \%)$ & \\
\hline Grade 3 & $3(4.5 \%)$ & $0(0.0 \%)$ & $0(0.0 \%)$ & \\
\hline Grade 4 & $1(1.5 \%)$ & $0(0.0 \%)$ & $1(16.7 \%)$ & \\
\hline
\end{tabular}

$H C V$ hepatitis $C$ virus, $A L T$ alanine transaminase, AST aspartate aminotransferase, T.bil total bilirubin

*Significant at $p \leq 0.05$ 
Table 3 Overall survival (OS) regarding different treatment regimens

\begin{tabular}{lllll}
\hline Treatment & $\begin{array}{l}\text { Number of } \\
\text { patients }\end{array}$ & \multicolumn{2}{l}{ OS months } \\
\cline { 3 - 5 } & & Range & (Mean \pm SD) & Median \\
\hline VCD & 54 & $1-156$ & $28.5 \pm 30.5$ & 20.3 \\
VRD & 10 & $3-63$ & $27.5 \pm 17.7$ & 26.4 \\
VTD & 8 & $12-77$ & $41.5 \pm 23.2$ & 44.5 \\
Endoxan-Dexa & 9 & $2-20$ & $8.13 \pm 6.9$ & 5.1 \\
\hline
\end{tabular}

$V C D$ Velcade $^{\oplus}$ (bortezomib)-cyclophosphamide-dexamethasone, VRD Velcade ${ }^{\bullet}$ (bortezomib)-Revlimid ${ }^{\oplus}$ (lenalidomide)-dexamethasone, VTD Velcade ${ }^{\circledR}$ (bortezomib)-thalidomide-dexamethasone;

Endoxan-Dexa endoxan-dexamethasone

versus anti $\mathrm{HCV}$ negative group (rates of grade 4 events, $16.7 \%$ vs. $1.5 \%, p$ value $=0.005$ ). The median HCV-RNA before the initiation of chemotherapy was $2.5 \mathrm{log} \mathrm{IU} / \mathrm{ml}$ with mean $\pm \mathrm{SD}=4.25 \pm 1.6$ with no $\mathrm{HCV}$ reactivation observed in our study. Three patients received antiviral treatment in the form of sofosbuvir (SOVALDI) by means of the Egyptian national campaign. Antiviral treatments were initiated after the course of MM chemotherapy. These 3 patients achieved sustained viral response (SVR) (HCV-RNA level measured at 3 months after completion of treatments). The other 3 patients died of causes not related to $\mathrm{HCV}$ infection, 2 patients received VCD, and their death was attributed to septic shock, severe chest infection, or pneumonia. The other one received VTD, and his death was attributed to intracranial hemorrhage which may be due to marked thrombocytopenia. MM patients were followed up according to available clinical data; the overall survival rate (OS: defined from the date of diagnosis till the date the patient died, or was last seen) and the disease-free survival rate (DFS: defined from the date of CR achievement till the date the patient relapsed) were assessed. OS regarding different MM treatment modalities is described in Table 3 . In the univariate and multivariate analysis, $\mathrm{HCV}$ infection was not an independent factor related to DFS. Low hemoglobin level $<10 \mathrm{~g} / \mathrm{dL}$ (HR 0.59, 95\% CI 0.36-0.97, $p$ value $=$ 0.037 ) and abnormal serum total bilirubin level (HR $1.9,95 \%$ CI $1.03-3.5, p$ value $=0.039)$ influenced DFS in the univariate analysis. However, in the multivariate analysis, serum calcium level greater than $12 \mathrm{mg} /$ $\mathrm{dL}(\mathrm{HR} 7.04,95 \%$ CI $1.12-44.45, p$ value $=0.038)$ and abnormal serum total bilirubin level (HR 10.9, 95\% CI 2.92-41.02, $p$ value $=<0.001)$ remained statistically significant worse prognostic factors as shown in Table 4. International staging system (ISS) did not affect DFS ( $p$ value $=0.587)$ as described in Table 5 and Fig. 1. Survival analysis according to different MM treatment modalities revealed statistically significant higher DFS rate in patients receiving Velcade (bortezomib)-thalidomide-dexamethasone as shown in Table 6 and Fig. 2.

\section{Discussion}

Multiple myeloma is a B cell malignancy involving terminally differentiated, non-dividing plasma cells that survive for months to years in the bone marrow and produce antigen-specific immunoglobulin, thus forming an integral part of the immune defense system [15]. For

Table 4 Univariate and multivariate analyses for DFS in MM patients

\begin{tabular}{|c|c|c|c|c|c|c|}
\hline \multirow[t]{2}{*}{ Items } & \multicolumn{3}{|c|}{ Univariate } & \multicolumn{3}{|c|}{ Multivariate } \\
\hline & HR & $95 \% \mathrm{Cl}$ & $P$ value & HR & $95 \% \mathrm{Cl}$ & $P$ value \\
\hline HCV status & 0.741 & $0.462,1.189$ & 0.214 & 0.797 & $0.386,1.645$ & 0.540 \\
\hline Age ( $\geq 65$ vs. < 65) & 1.545 & $0.553,4.315$ & 0.407 & 1.782 & $0.340,9.337$ & 0.494 \\
\hline Gender (male vs. female) & 1.003 & $0.613,1.643$ & 0.989 & 0.986 & $0.429,2.262$ & 0.973 \\
\hline ISS stage & 0.865 & $0.615,1.214$ & 0.406 & 1.367 & $0.558,3.352$ & 0.494 \\
\hline$\beta 2 \mathrm{~m}$ ( $\geq 3.5$ vs. $<3.5 \mathrm{mg} / \mathrm{L})$ & 0.941 & $0.475,1.863$ & 0.861 & 0.329 & $0.057,1.89$ & 0.213 \\
\hline Albumin $(<3.5 \mathrm{vs} \geq 3.5 \mathrm{~g} / \mathrm{L})$ & 1.058 & $0.639,1.749$ & 0.827 & 1.282 & $0.504,3.262$ & 0.602 \\
\hline Hemoglobin (< 10 vs. $\geq 10 \mathrm{~g} / \mathrm{dL}$ ) & 0.592 & $0.361,0.970$ & $0.037^{*}$ & 0.604 & $0.284,1.287$ & 0.191 \\
\hline Platelets (< 100 vs. $\geq 100 \times 109 / L)$ & 0.780 & $0.385,1.579$ & 0.490 & 0.784 & $0.072,7.763$ & 0.808 \\
\hline Serum calcium ( $\geq 12$ vs. $<12$ mg/dL) & 3.253 & $0.767,13.795$ & 0.110 & 7.042 & $1.12,44.45$ & $0.038^{*}$ \\
\hline Serum creatinine $(\geq 2.0$ vs. $<2.0 \mathrm{mg} / \mathrm{dL}$ & 1.123 & $0.534,2.362$ & 0.760 & 0.741 & $0.162,3.384$ & 0.699 \\
\hline Serum ALT (abnormal vs. normal) & 0.973 & $0.236,4.003$ & 0.969 & -- & -- & -- \\
\hline Serum AST (abnormal vs. normal) & 1.055 & $0.545,2.042$ & 0.874 & 0.472 & $0.125,1.782$ & 0.268 \\
\hline Serum T. bil. (abnormal vs. normal) & 1.902 & $1.034,3.50$ & $0.039^{*}$ & 10.94 & $2.92,41.02$ & $<0.001^{*}$ \\
\hline
\end{tabular}

$H R$ hazard ratio, $C l$ confidence interval, $H C V$ hepatitis $C$ virus, $\beta 2 m$ beta-2-microglobulin, ISS International Staging System, $A L T$ alanine transaminase, $A S T$ aspartate aminotransferase, T.bil total bilirubin

*Significant at $p \leq 0.05$ 
Table 5 Kaplan-Meier analysis for DFS between the different ISS stages

\begin{tabular}{llllll}
\hline ISS stages & Mean DFS & $\mathbf{9 5 \%} \mathbf{C l}$ & Median & $\mathbf{9 5 \%} \mathbf{C l}$ & $\boldsymbol{P}$ value \\
\hline I & 22.905 & $0.0,46.6$ & 5.000 & $0.0,10.4$ & 0.587 \\
|| & 30.537 & $14.6,46.5$ & 16.000 & 11,21 & \\
III & 24.933 & $15.4,34.5$ & 14.000 & $3.9,24.1$ & \\
\hline
\end{tabular}

*Significant at $p \leq 0.05$

MM patients, the impact of preexisting $\mathrm{HCV}$ infection is unclear, and also, the mechanisms by which HCV may cause myeloma are less explored. The aim of the current study is to explore the clinical characteristics and prevalence of the hepatitis $C$ virus infections in Egyptian multiple myeloma patients. In our study, the prevalence of $\mathrm{HCV}$ infections in Egyptian myeloma patients revealed that $15 / 81(18.5 \%)$ patients were anti-HCV positive. For more accurate confirmation, RT-PCR was done. Out of 15 anti-HCV positive patients, $9(11.1 \%)$ patients are $\mathrm{HCV}$ RNA negative while the remaining patients $(6 / 15 ; 7.4 \%)$ are HCV RNA positive. Several studies have explored the prevalence and pathogenic role of $\mathrm{HCV}$ infection in hematological malignancies especially in lymphoproliferative disorders (LPDs), including MM. There is heterogeneity in identifying $\mathrm{HCV}$ infection status, with the majority of studies defined $\mathrm{HCV}$ infection as positivity for $\mathrm{HCV}$ antibody only such as Cavanna et al., Musto et al., Teng et al., and Takeshita et al. who reported a higher prevalence of $\mathrm{HCV}$ infection in LPDs patients including MM $(16.7 \%, 11.1 \%, 9 \%$, and $4.9 \%)$, respectively $[13,16-18]$. However, Silvestri et al. revealed that the prevalence and relative risk of being infected by $\mathrm{HCV}$ is higher in B nonHodgkin lymphoma but not MM patients [19]. Moreover, Vener et al. and Anderson et al. reported no increase of $\mathrm{HCV}$ prevalence in patients with $\mathrm{MM}(0.7 \%$ and $0.2 \%)$, respectively [20, 21]. Okan et al. defined HCV positivity as positivity for both HCV antibody and HCV RNA, and this study revealed no significant difference in the combined prevalence of $\mathrm{HBV}$ and $\mathrm{HCV}$ infections in patients with LPD [22], whereas De Rosa et al. defined HCV positivity as positivity in either HCV antibody or HCV RNA and reported $16.1 \%$ prevalence of $\mathrm{HCV}$ infection in patients with B-LPD including MM [23]. The incidence of hepatic adverse events in our MM patients revealed that hyperbilirubinemia with grade 4 adverse events was significantly higher in the anti-HCV positive/HCV RNA positive group versus anti-HCV negative group $(16.7 \%$ vs. $1.5 \%, p$ value $=$ 0.005). This is in accordance with Teng et al. who found that MM patients who were chronic viral hepatitis carriers experienced more and earlier hepatic adverse events during treatment which could not be explained by the difference in the therapies received [13]. Finally, as MM is a B cell lymphoproliferative disease, the possible $\mathrm{HCV}$ carcinogenic effect leading to lymphoma development may also play a role in MM development. HCV directly changes the lymphocyte phenotype through different types of protein, indirectly fuel the growth of B cells or an unknown infectious agent may affect lymphomagenicity in $\mathrm{HCV}$ infection [24]. Moreover, HCV viral proteins have been identified in $\mathrm{B}$ cells of $\mathrm{HCV}$-infected patients. In addition, there was upregulated $B$ cell receptor (BCR) signaling in human primary B cells of HCV-infected patients [25], which may contribute to a better understanding of

Survival Functions

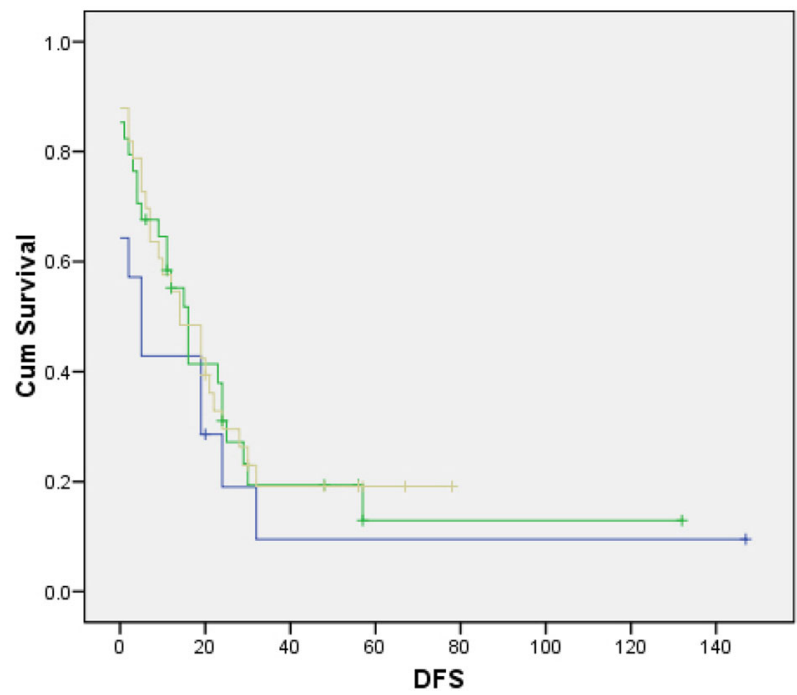

ISS

$\square 1$

$-3$

+1 -censored

+2 -censored

3-censored

Fig. 1 Kaplan-Meier analysis for DFS between the different ISS stages 
Table 6 Kaplan-Meier analysis for DFS between the different treatment regimens

\begin{tabular}{llllll}
\hline & Mean DFS & $\mathbf{9 5 \%} \mathrm{Cl}$ & Median & $\mathbf{9 5 \%} \mathrm{Cl}$ & $\boldsymbol{p}$ value \\
\hline Endoxan-Dexa & 4.444 & $0.6,8.3$ & 3 & $0.0,11.8$ & $<0.001^{*}$ \\
VCD & 29.511 & $16.4,42.6$ & 14 & $6.8,21.2$ & \\
VRD & 25.613 & $16.1,35.2$ & 24 & $17.5,30.5$ & \\
VTD & 44.063 & $24,64.1$ & - & - & \\
\hline
\end{tabular}

*Significant at $p \leq 0.05$

VCD Velcade ${ }^{\circledast}$ (bortezomib)-cyclophosphamide-dexamethasone, VRD Velcade ${ }^{\oplus}$ (bortezomib)-Revlimid ${ }^{\circledast}$ (lenalidomide)-dexamethasone, VTD Velcade ${ }^{\circledR}$ (bortezomib)-thalidomide-dexamethasone,

Endoxan-Dexa endoxan-dexamethasone

the molecular mechanisms underlying MM. In addition to the above mechanisms by which HCV may cause myeloma, there is a therapeutic dilemma in the clinical settings for treating MM patients infected by HCV. Several studies found $\mathrm{HCV}$ reactivation or acute exacerbation in $\mathrm{HCV}$-infected patients taken chemotherapeutic agents, such as protocols including corticosteroids or thalidomide [26]. Corticosteroids may enhance HCV viral RNA replication or suppress HCV-mediated immune response [27]. Also, thalidomide may inhibit activation of ІкB kinase and signaling of nuclear factor- $\mathrm{kB}$, which leads to enhanced replication of HCV viral RNA [28]. Notably, Mahale et al. [29] revealed that chemotherapeutic agents may not lead to viral relapse in cancer patients infected with $\mathrm{HCV}$ and treated with antiviral drugs. Therefore, early $\mathrm{HCV}$ infection identification and treatment is necessary before starting chemotherapeutic agents in MM patients. Our data showed that patients who receive VTD as induction therapy have higher DFS. Though there is a selection bias in treatment considerations for our patients, as patients with younger age and higher risk or higher disease burden (by $\beta_{2} \mathrm{M}$ or PET scan), were considered to receive VRD. So this explains the poorer survival in this group. Patients living at distant areas from our department, who have difficulties in coming to the clinic weekly, receive VTD as induction, while VCD remains the most common standard regimen given to our patients and this explains the moderate survival for this group. Finally, limitations of this study include small sample size; thus, this work should be extended on wider prospective clinical studies with larger patient series and longer follow-up period to assess the clinical impact of HCV infection in Egyptian MM patients and to validate whether increased risk of $M M$ in patients with $\mathrm{HCV}$ infection is due to its actual risk factor or due to high prevalence of $\mathrm{HCV}$ infection in our population. In addition, the association between cytogenetic abnormalities in MM patients and HCV infection warrants further study to clarify the relationship.

\section{Conclusion}

In conclusion, our study revealed the prevalence of $\mathrm{HCV}$ infection in Egyptian MM patients. Serologic tests at diagnosis are necessary to identify these patients, and confirmation of positive cases by molecular techniques should be mandatory, with regular follow-up for liver dysfunction. Finally, further larger studies explaining the molecular mechanisms linking HCV and the MM pathogenesis are warranted.

\section{Survival Functions}

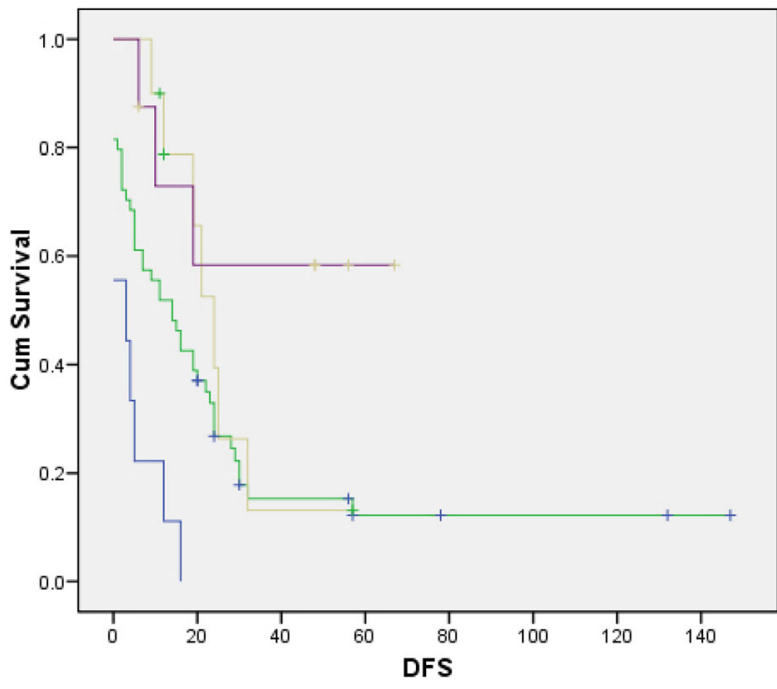

Cth induction

$\neg$ Endoxan-Dexa

$\neg \mathrm{VCD}$

$\because \mathrm{VRD}$

$\neg V$ TTD

+ VCD-censored

+ VRD-censored

VTD-censored

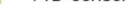




\section{Abbreviations}

ALT: Alanine transaminase; ASCT: Autologous stem cell transplantation; AST: Aspartate aminotransferase; BCR: B cell receptor; BM: Bone marrow; $\mathrm{Cl}$ : Confidence interval; CMIA: Chemiluminescent microparticle immunoassay; CR: Complete remission; DFS: Disease-free survival; Endoxan-Dexa: Endoxandexamethasone; FLC: Free light chain; HCC: Hepatocellular carcinoma; HCV Ab: Hepatitis C virus antibodies; HCV: Hepatitis C virus; HR: Hazard ratio; ISS: International Staging System; LPDs: Lymphoproliferative disorders; MGUS: Monoclonal gammopathy of undetermined significance; MM: Multiple myeloma; OS: Overall survival; PCR: Polymerase chain reactions; PCs: Plasma cells; PD: Progressive disease; POEMS: Polyneuropathy, organomegaly, endocrinopathy, monoclonal gammopathy, and skin changes syndrome; PR: Partial response; SD: Standard deviation; ST: Stationary disease; SVR: Sustained viral response; T.bil: Total bilirubin; VCD: Velcade ${ }^{\oplus}$ (bortezomib)-cyclophosphamide-dexamethasone; VGPR: Very good partial response; VRD: Velcade ${ }^{\oplus}$ (bortezomib)-Revlimid ${ }^{\oplus}$ (lenalidomide)dexamethasone; VTD: Velcade ${ }^{\oplus}$ (bortezomib)-thalidomide-dexamethasone; $\beta_{2}$ m: Beta-2-microglobulin

\section{Acknowledgements}

We deeply acknowledge the scientific and technical support offered by Clinical Oncology dep. molecular lab team. We are also thankful for our dear patients as well as IT dep. team.

\section{Authors' contributions}

NK analyzed and interpreted the patient data. HK was responsible for data analysis and was a major contributor in writing the manuscript. MI performed the statistical analysis of our study. HZ was responsible for demographic and clinical data collection. EH analyzed and interpreted the patient data. All authors read and approved the final manuscript.

\section{Funding}

This study was funded by Kasr Al Ainy Clinical Oncology dep., Cairo University, which provides us with the needed kits. Needed laboratory analysis was performed in molecular Lab. of Kasr Al-Ainy Clinical Oncology dep. with the availability of all equipments needed in our study.

\section{Availability of data and materials}

The datasets used and/or analyzed during the current study are available from the corresponding author on reasonable request.

\section{Ethics approval and consent to participate}

This study was approved by Kasr Al Ainy Clinical Oncology department Institutional Review Board (IRB)-1-2018. Written informed consent was obtained from all individual participants included in the study. All procedures performed in the study involving human participants were in accordance with the ethical standards of the institutional research committee and with the 1964 Helsinki declaration and its later amendments (GCP guidelines) or comparable ethical standards.

\section{Consent for publication}

The consent to publish had been taken from each participant in this work.

\section{Competing interests}

The authors declare that they have no competing interests.

\section{Author details}

'Clinical and Chemical Pathology Department, Kasr Al Ainy Centre of Clinical Oncology \& Nuclear Medicine, School of Medicine, Cairo University, Cairo, Egypt. ${ }^{2}$ Gynecology \& Obstetric Department, School of Medicine, Cairo University, Cairo, Egypt. ${ }^{3}$ Clinical Oncology Department, School of Medicine, Cairo University, Cairo, Egypt.

Received: 20 July 2020 Accepted: 18 October 2020

Published online: 27 November 2020

\section{References}

1. Kassem NM, EL Zawam H, Kassem HA, EL Nahas T, El Husseiny NM, Abd El Azeeim H. A descriptive study of plasma cell dyscrasias in Egyptian population. J Egypt Natl Cancer Inst. 2014;26:67-71.
2. Walker BA, Boyle EM, Wardell CP, Murison A, Begum DB, Dahir NM, et al. Mutational spectrum, copy number changes, and outcome: results of a sequencing study of patients with newly diagnosed myeloma. J Clin Oncol. 2015:33:3911-20.

3. Hu Y, Chen W, Wang J. Progress in the identification of gene mutations involved in multiple myeloma. Onco Targets Ther. 2019;12:4075-80.

4. Abd El Kader Y, Emera G, Safwat E, Kassem H, Kassem N. The KRAS StripAssay for detection of KRAS mutation in Egyptian patients with colorectal cancer (CRC): a pilot study. J Egypt Natl Cancer Inst. 2013;25:37-41.

5. Hashem AM, Fahmy HM, Abdo ES, et al. Prevalence of occult hepatitis C virus infection in patients with multiple myeloma. Med J Cairo Univ. 2015; 83:507-13.

6. Bird SA, Boyd K. Multiple myeloma: an overview of management. Palli Care Social Practice. 2019;13:1-13.

7. Globocan 2018. https://gco.iarc.fr/today/data/factsheets/populations/818egypt-fact-sheets.pdf.

8. Petruzziello A, Marigliano S, Loquercio G, Cozzolino A, Cacciapuoti C. Global epidemiology of hepatitis $C$ virus infection: an up-date of the distribution and circulation of hepatitis C virus genotypes. World J Gastroenterol. 2016; 22(34):7824-40.

9. El-Ghitany EM. Hepatitis C virus infection in Egypt: current situation and future perspective. J High Inst Public Health. 2019;49(1):1-9.

10. Talima S, Kassem H, Kassem N. Chemotherapy and targeted therapy for breast cancer patients with hepatitis C virus infection. Breast Cancer. 2019; 26:154-63.

11. Li Y, Li Y, Zhang L, Li W. Hepatitis C virus infection and risk of multiple myeloma: evidence from a meta-analysis based on 17 case-control studies. J Viral Hepat. 2017;24:1151-9.

12. Farawela H, Khorshied M, Shaheen I, Gouda H, Nasef A, Abulata N, et al. The association between hepatitis $C$ virus infection, genetic polymorphisms of oxidative stress genes and B-cell non-Hodgkin's lymphoma risk in Egypt. Infect Genet Evol. 2012 Aug;12(6):1189-94.

13. Teng CJ, Liu HT, Liu CY, et al. Chronic hepatitis virus infection in patients with multiple myeloma: clinical characteristics and outcomes. Clinics (Sao Paulo, Brazil). 2011;66:2055-61.

14. McGovern BH, Birch CE, Bowen MJ, Reyor LL, Nagami EH, Chung RT, et al. Improving the diagnosis of acute hepatitis $C$ virus infection with expanded viral load criteria. Clin Infect Dis. 2009:49:1051-60.

15. Bianchi G, Munshi NC. Pathogenesis beyond the cancer clone(s) in multiple myeloma. Blood. 2015;125:3049-58.

16. Cavanna L, Sbolli G, Tanzi E, Romanò L, Civardi G, Buscarini E, et al. High prevalence of antibodies to hepatitis $C$ virus in patients with lymphoproliferative disorders. Haematologica. 1995;80:486-7.

17. Musto P, Dell'Olio M, Carotenuto M, Mangia A, Andriulli A. Hepatitis C virus infection: a new bridge between hematologists and gastroenterologists? Blood. 1996;88:752-4.

18. Takeshita M, Sakai H, Okamura S, Higaki K, Oshiro Y, Uike N, et al. Prevalence of hepatitis $C$ virus infection in cases of B-cell lymphoma in Japan. Histopathology. 2006:48:189-98.

19. Silvestri F, Pipan C, Barillari G, Zaja F, Fanin R, Infanti L, et al. Prevalence of hepatitis $C$ virus infection in patients with lymphoproliferative disorders. Blood. 1996;87:4296-301.

20. Veneri D, Franchini M, Zanotti R, Frattini F, Randon F, Rinaldi M, et al. Prevalence of hepatitis $C$ virus infection among patients with lymphoproliferative disorders: a single center survey. Am J Hematol. 2007; 82:1031.

21. Anderson LA, Pfeiffer R, Warren JL, Landgren O, Gadalla S, Berndt SI, et al. Hematopoietic malignancies associated with viral and alcoholic hepatitis. Cancer Epidemiol Biomark Prev. 2008;17:3069-75.

22. Okan V, Yilmaz M, Bayram A, Kis C, Cifci S, Buyukhatipoglu H, et al. Prevalence of hepatitis $B$ and $C$ viruses in patients with lymphoproliferative disorders. Int J Hematol. 2008;88:403-8.

23. De Rosa G, Gobbo ML, De Renzo A, Notaro R, Garofalo S, Grimaldi M, et al. High prevalence of hepatitis C virus infection in patients with B-cell lymphoproliferative disorders in Italy. Am J Hematol. 1997;55:77-82.

24. Matsuo K, Kusano A, Sugumar A, Nakamura S, Tajima K, Mueller NE. Effect of hepatitis C virus infection on the risk of non-Hodgkin's lymphoma: a metaanalysis of epidemiological studies. Cancer Sci. 2004;95:745-52.

25. Dai $B$, Chen $A Y$, Corkum CP, et al. Hepatitis $C$ virus upregulates $B$-cell receptor signaling: a novel mechanism for HCV-associated B-cell lymphoproliferative disorders. Oncogene. 2016;35:2979-90. 
26. Mahale P, Thomas SK, Kyvernitakis A, Torres HA. Management of multiple myeloma complicated by hepatitis $C$ virus reactivation: the role of new antiviral therapy. Open Forum Infec Dis. 2016;3:ofv211.

27. Henry SD, Metselaar HJ, Van Dijck J, Tilanus HW, Van Der Laan LJ. Impact of steroids on hepatitis C virus replication in vivo and in vitro. Ann N Y Acad Sci. 2007;1110:439-47.

28. Rance $E$, Tanner JE, Alfieri C. Inhibition of IkB kinase by thalidomide increases hepatitis C virus RNA replication. J Viral Hepat. 2012;19:e73-80.

29. Mahale $P$, Okhuysen PC, Torres HA. Does chemotherapy cause viral relapse in cancer patients with hepatitis $C$ infection successfully treated with antivirals? Clin Gastroenterol Hepatol. 2014;12:e1.

\section{Publisher's Note}

Springer Nature remains neutral with regard to jurisdictional claims in published maps and institutional affiliations.

\section{Submit your manuscript to a SpringerOpen ${ }^{\circ}$ journal and benefit from:}

- Convenient online submission

- Rigorous peer review

- Open access: articles freely available online

High visibility within the field

- Retaining the copyright to your article

Submit your next manuscript at $\boldsymbol{\nabla}$ springeropen.com 